\title{
Can birds play a role as High Nature Value indicators of montado system?
}

\author{
L. Catarino $\cdot$ C. Godinho $\cdot$ P. Pereira • \\ A. Luís · J. E. Rabaça
}

Received: 21 April 2014/ Accepted: 29 October 2014

(C) Springer Science+Business Media Dordrecht 2014

\begin{abstract}
Montados form a heterogeneous landscape of wooded matrix dominated by cork and/or holm oak with open areas characterized by fuzzy boundaries. Montado supports a high biological diversity associated to low intensity management and a landscape diversity provided by a continuous gradient of land cover. Among other features this permits the classification of montados as a High Nature Value (HNV) system. We assessed the role of birds as HNV indicators for montado, and tested several bird groups-farmland, edge, forest generalists and forest specialists species; and some universal
\end{abstract}

Electronic supplementary material The online version of this article (doi:10.1007/s10457-014-9761-y) contains supplementary material, which is available to authorized users.

L. Catarino - C. Godinho - P. Pereira - J. E. Rabaça

LabOr - Laboratório de Ornitologia, ICAAM,

Universidade de Évora, 7002-554 Évora, Portugal

C. Godinho $(\bowtie) \cdot$ P. Pereira · J. E. Rabaça

ICAAM - Instituto de Ciências Agrárias e Ambientais Mediterrânicas, Universidade de Évora, Núcleo da Mitra, Ap. 94, 7002-554 Évora, Portugal

e-mail: capg@uevora.pt

A. Luís

Departamento de Biologia, Universidade de Aveiro, Campus de Santiago, 3810-193 Aveiro, Portugal

J. E. Rabaça

Departamento de Biologia, Universidade de Évora, 7002-554 Évora, Portugal indicators such as species conservation status, Shannon's diversity index and species richness. Our study areas covered the North-South distribution of cork oak in Portugal, and we surveyed the breeding bird communities across 117 sampling sites. In addition to variables related to management and sanitary status, we considered variables that characterize the landscape heterogeneity inside the montado-trees and shrub density and richness of woody vegetation. Our results suggest that specific bird guilds can be used as $\mathrm{HNV}$ indicators of particular typologies of montado, and highlight the need to develop an indicator that could be transversally applied to all types of montado.

Keywords Montados - Birds · HNV farmland · Indicators $\cdot$ Landscape composition

\section{Introduction}

Portuguese montados and Spanish dehesas are silvopastoral systems of anthropogenic origin derived from ancient Mediterranean forests of cork oaks (Quercus suber) or holm oaks (Quercus rotundifolia). These systems can combine the use of woodland products (e.g. timber, charcoal and cork) with cereal crops and livestock grazing in the understory (Blondel and Aronson 1999). Such diversified activities allow montados to form a heterogeneous landscape of wooded matrix with open areas, scattered woodlands 
and semi-natural patches of Mediterranean forest and scrublands, resulting in a system with high biological diversity (Rabaça 1990; Blondel and Aronson 1999; Tellería 2001; Díaz et al. 2003; Telleria et al. 2003; Harrop 2007). This mosaic of habitats has been widely recognized as an hotspot of farmland biodiversity and exponents of landscape multifunctionality (PintoCorreia et al. 2011a).

We focused our study on cork oak montados due to the relevance of the area they occupy in Portugal - c. 737,000 ha (DGRF 2007) - and its influence on national economy, representing $1 \%$ of the GNP (APCOR 2012). Currently, Portugal harbors $34 \%$ of the world distribution of montados, holding half of the cork production of the world. Cork exploitation is highly sustainable, since the cork oak tree possesses the particular ability of producing a cork layer in the bark that regenerates after the debarking process. This biological feature allows the extraction of the bark from the tree in nine-year cycles without resulting in the death of the tree.

Despite its economic and environmental relevance, montados have been exposed to several pressures and threats, mainly intensification, overgrazing, land abandonment and the spreading of pathogenic agents (Plieninger 2007), but also extensification through lower grazing density and lower shrub control (PintoCorreia and Almeida 2013). Therefore, management options able to conciliate the maintenance of biodiversity and the economic values of the montado are critical, and objective criteria must be described for the functioning of the system and for the services it provides (Andersen et al. 2003). This is particularly relevant regarding the High Nature Value (HNV) classification, which aims to integrate biodiversity and environmental concerns in the agricultural sector (Beaufoy and Cooper 2008). The HNV concept involves low intensity farming, presence of seminatural vegetation (e.g. hedgerows, uncultivated fields/patch's, shrubs, scattered trees) and diversity of land cover, that sustains or is associated to areas with high species diversity or to the presence of priority species for conservation at European, national or regional scale (Andersen et al. 2003; Hoffmann and Greef 2003; Kleijn et al. 2009).

According to the classification proposed by the European Environment Agency, most of the silvopastoral systems in the Iberian Peninsula are considered HNV systems (Hoogeveen et al. 2004). However, unlike forestry systems such as pine (Pinus spp.) plantations (Scarascia-Mugnozza et al. 2000), the diverse and most common management activities conducted in montados throughout the year (e.g. agriculture, pasture, grazing, livestock, game, etc.) are known to increase the structural complexity of the system, producing several types of montado in different natural conditions and different management contexts (Pinto-Correia 1993; Pinto-Correia and Almeida 2013). Hence, the question raised by PintoCorreia and Almeida (2013) remains: can all montados typologies be classified as HNV systems?

It is recognized that montados exhibit the highest richness of communities of breeding birds associated with forested areas in the Iberian Peninsula (Tellería 2001). Moreover, many bird species seem to be well adapted to this system and several species even show a tolerance to debark (Godinho and Rabaça 2011; Leal et al. 2011).

When compared with other HNV systems, montados have a major forest component which increases its structural complexity. Since communities of breeding birds have long been recognized as good indicators of the structural complexity of forested areas (e.g. Willson 1974; Rabaça 1990; Whelan 2001, Pereira et al. 2014), we used assemblages of breeding birds to evaluate: (1) which features of montado contribute to higher species diversity and richness, (2) if these parametersdiversity and richness - and/or bird guilds can be used to identify montado areas to be classified as $\mathrm{HNV}$, and (3) if a specific bird guild can better represent montado natural values than community parameters like species richness or diversity.

\section{Methods}

Study area

We sampled four areas covering the main distribution range of cork oak in Portugal (Fig. 1): the Site of Community Importance (SCI) of Romeu (hereafter Romeu) with several private owners $\left(7^{\circ} 1^{\prime}-7^{\circ} 6^{\prime} \mathrm{W}\right.$ and $41^{\circ} 33^{\prime}-41^{\circ} 28^{\prime} \mathrm{N}$ ), Companhia das Lezírias S.A. (Lezírias) a public ownership farm $\left(8^{\circ} 48^{\prime} \mathrm{W}\right.$ and $38^{\circ} 50^{\prime} \mathrm{N}$ ), SCI Serra de Monfurado (Monfurado) $\left(7^{\circ} 40^{\prime}-8^{\circ} 16^{\prime} \mathrm{W}\right.$ and $\left.38^{\circ} 27^{\prime}-38^{\circ} 41^{\prime} \mathrm{N}\right)$ and Serra de Grândola (Grândola) $\left(8^{\circ} 34^{\prime}-8^{\circ} 38^{\prime} \mathrm{W}\right.$ and $38^{\circ} 9^{\prime}-$ 
Fig. 1 Location of the study areas in Portugal

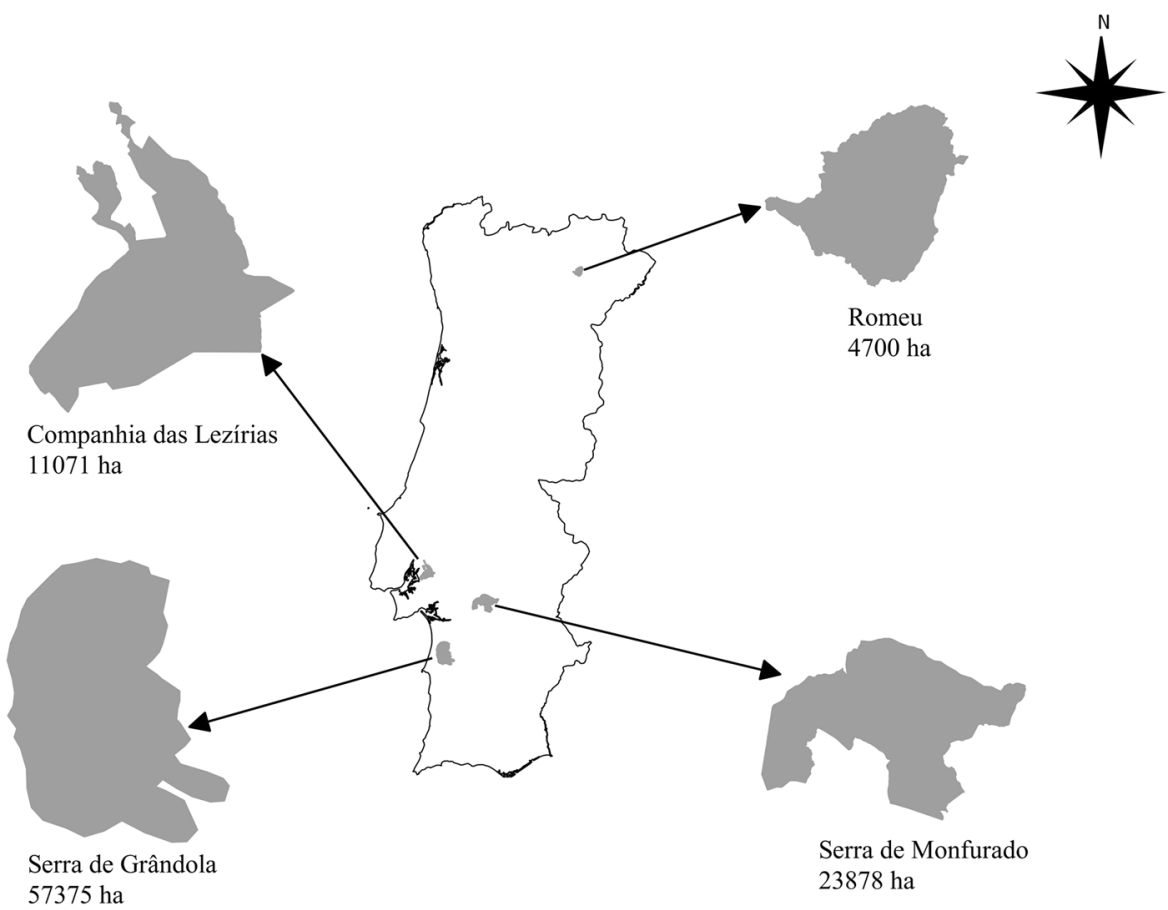

$38^{\circ} 08^{\prime} \mathrm{N}$ ) both with several private owners. These areas reflect the most common typologies of montados, half of the national distribution of cork oak has a tree coverage between 10 and $30 \%$, a quarter between 30 and $50 \%$ and a quarter superior to $50 \%$ (Carreiras et al. 2006). Our sampling sites represent these three categories in a similar proportion. Lezírias and Monfurado had sites belonging to all categories; sites with higher tree cover were absent and in Romeu and Grândola (Fig. 2). These areas are located in the Mediterranean part of the country (Northeast and the entire Southern half of Portugal), characterized by hot and dry summers and moderate rainy winters. Altitude ranges between $15 \mathrm{~m}$ (Lezírias) and $600 \mathrm{~m}$ (Romeu). Romeu and Monfurado showed the lowest mean annual temperature $\left(12.3\right.$ and $12.5{ }^{\circ} \mathrm{C}$, respectively) and the highest levels of mean annual precipitation (760 and $800 \mathrm{~mm}$, respectively). Lezírias and Grândola showed a mean annual temperature of 15.7 and $15.6{ }^{\circ} \mathrm{C}$, respectively, and lower levels of mean annual precipitation (644 and $500 \mathrm{~mm}$, correspondingly). The woodland area is dominated by cork oaks, but holm oak settlements can be found in Monfurado and mixed stands with cork oak, maritime pine (Pinus pinaster) and stone pine (Pinus pinea) occur in Lezírias. Other common land uses are: rice fields, vineyards and pine woods in Lezírias; olive groves, small orchards, dry cereal fields and fallows in Monfurado; and olive groves and vineyards in Romeu. Riparian galleries are present in all areas.

Bird census

We carried out bird censuses in Monfurado (2011) and in the other areas (2012) during the breeding seasons (between April and May). We gathered data on bird species using 10 min point counts (e.g. Bibby et al. 2000) with $100 \mathrm{~m}$ radius. We conducted surveys between 6:00 and 11:00 a.m., when birds are more active, and we avoided days with hard wind and rain. In each study area we surveyed 30 sites except in Romeu where we sampled 27 points. Our four areas covered a wide range of the different montado typologies present in Portugal (Fig. 2), and sites were randomly selected, as long as they satisfied two criteria: (1) accessibility and (2) being situated at least $500 \mathrm{~m}$ apart from each other to minimize the probability of double counting birds. Three experienced observers with similar skills of bird detection conducted the surveys. 
Fig. 2 Distribution of sampling sites along a gradient of montado coverage

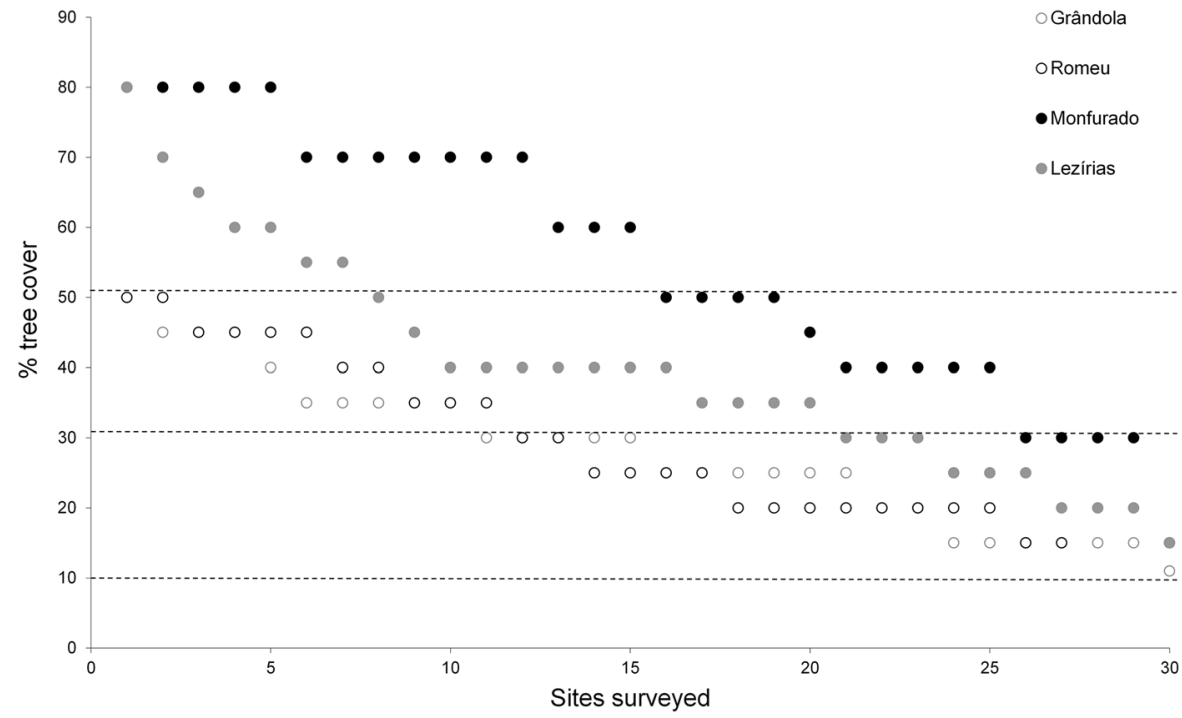

We excluded aerial-feeding birds (e.g. barn swallow Hirundo rustica) from data treatment, as well as species with known large home-ranges (e.g. carrion crow Corvus corone and raven C. corax).

We used the species richness of each of the following four ecological guilds (farmland species, edge species, forest generalists and forest specialists) defined according to their habitat preferences in the Mediterranean part of Portugal during the breeding season (Table 1). Species classification is related to the specialization degree taking into account the habitats occupied along a gradient of natural terrestrial habitats, and may not be applicable outside this geographic area or time of year. This gradient can be represented by an increased complexity of vegetation structure, from structurally simpler habitats such as grasslands to intermediate habitats as heathlands and scrublands culminating in oak forests (such as cork oak or holm oak). To this end, we used the available information regarding places and strategies used to capture food, sites used for territorial defence as well as nesting sites. Farmland species mostly occur in association with open fields or, at most, with scattered shrubs or trees; edge species are associated with transitional areas that can occur at boundaries between two or more habitats (e.g. forest and open areas); forest generalists occur at any woody areas, regardless of the density and height of the tree formations; forest specialists tend to occupy stable forest environments and are therefore more sensitive to human disturbance than generalist forest species. Most occur in natural or semi-natural forests with the following features: (1) high canopy of great maturity, (2) large stratification of woody vegetation, and (3) humid microclimate.

In addition to ecological guilds we also considered Shannon's diversity index (ShInd), total species richness (SpRich) and a variable that takes into account the richness of species with conservation status (ConSt). This variable was estimated as the richness by point count of species listed in at least one of these lists: the Red Book of Vertebrates of Portugal (Cabral et al. 2005), Species of European Conservation Concern (BirdLife International 2004) and IUCN Red List for Birds (BirdLife International 2014).

HNV features and explanatory variables

Due to their nature, montado landscapes are distinguished by fuzzy boundaries with overlapping land cover classes (diverse combinations of forest cover, grass and shrubs) (Pinto-Correia and Vos 2004), they are often characterized by gradual changes in shrub and tree densities, resulting from the combination of different levels of land use and of variable, extensive land use practices. The fuzziness of the boundaries is inherent to the land use system and should be accepted as such. Small differences in terms of tree density and shrub cover reflect important differences in abiotic factors (Joffre et al. 1999), types of the management in the past and present (Pinto-Correia 1993) and levels of biodiversity (Ojeda et al. 1995). 
Table 1 Ecological guilds based on species habitat preferences

\begin{tabular}{|c|c|c|}
\hline Bird guild & Definition criteria & Species \\
\hline $\begin{array}{l}\text { Forest } \\
\text { specialists }\end{array}$ & Species that occur only in certain forest types & $\begin{array}{l}\text { Dendrocopos minor, Troglodytes troglodytes, Erithacus } \\
\text { rubecula, Phoenicurus phoenicurus, Sylvia atricapilla, } \\
\text { Phylloscopus bonelli, Phylloscopus ibericus, Aegithalos } \\
\text { caudatus, Sitta europaea, Coccothraustes } \\
\text { coccothraustes }\end{array}$ \\
\hline $\begin{array}{l}\text { Forest } \\
\text { generalists }\end{array}$ & $\begin{array}{l}\text { Forest species that occur in any woody areas, regardless } \\
\text { of the density and height of the plant formations, as } \\
\text { well as bioclimatic conditions of the site }\end{array}$ & $\begin{array}{l}\text { Columba palumbus, Cuculus canorus, Dendrocopos } \\
\text { major, Luscinia megarhynchos, Turdus merula, Sylvia } \\
\text { melanocephala, Parus cristatus, Parus caeruleus, Parus } \\
\text { major, Certhia brachydactyla, Garrulus glandarius, } \\
\text { Oriolus oriolus, Fringilla coelebs, Serinus serinus, } \\
\text { Carduelis chloris }\end{array}$ \\
\hline $\begin{array}{l}\text { Edge } \\
\text { species }\end{array}$ & $\begin{array}{l}\text { Species that occur at the boundary between two or more } \\
\text { habitats }\end{array}$ & $\begin{array}{l}\text { Streptopelia turtur, Clamator glandarius, Jynx torquilla, } \\
\text { Lullula arborea, Hippolais polyglotta, Sylvia undata, } \\
\text { Sylvia cantillans, Lanius meridionalis, Lanius senator, } \\
\text { Passer montanus, Petronia petronia, Carduelis } \\
\text { carduelis, Carduelis cannabina, Emberiza cirlus, } \\
\text { Emberiza cia }\end{array}$ \\
\hline $\begin{array}{c}\text { Farmland } \\
\text { species }\end{array}$ & Farmland species that tolerate low tree densities & $\begin{array}{l}\text { Alectoris rufa, Coturnix coturnix, Upupa epops, Galerida } \\
\text { theklae, Oenanthe hispanica, Saxicola torquata, } \\
\text { Cisticola juncidis, Sturnus unicolor, Passer domesticus, } \\
\text { Emberiza calandra }\end{array}$ \\
\hline
\end{tabular}

We recorded environmental variables for each sampling site that, according to our rationale, could represent the heterogeneity within the montado: (1) tree density; (2) shrub density; (3) woody richness; (4) type of edge and; (5) distance to edge (Table 2). We also recorded geographical variables (location and altitude), management variables (trunk diameter at breast height, debark), and variables associated with the sanitary status of the settlements (occurrence of pests outbreaks and fungal presence) (Table 2).

Immediately after conducting the bird censuses, we evaluated the vegetation features within a $100 \mathrm{~m}$ radius around the centre of the point count.

At each point of the study areas, the sanitary status of the oak woodlands was evaluated through visual assessment of five oaks separated $10 \mathrm{~m}$ from each other, avoiding trees with adjoined crowns. We detected the damage made by buprestids Coroebus florentinus and Coroebus undatus through the presence of typical dead branches on outer-canopy and the presence of feeding galleries of larvae on the cork layer, respectively. These measures were used as individual variables, but also incorporated together with insect trunk holes of bark beetle (Platypodidae and Scolytidae), cerambycids (Cerambycidae) and signs of fungal disease Biscogniauxia mediterranea to create a sanitary index (San). We created the sanitary index for montado according to the level of harm done by insect pests on the sampling sites. For each insect pest and fungus we attributed a coefficient of impact according to the intensity of their damage on the tree: 1-high aesthetic impact with low economic or ecological relevance (C. florentinus), 3-high economic relevance due to loss of cork value (C. undatus), 5 - associated with tree decline or death (bark beetles, cerambycids and $B$. mediterranea).

We created the sanitary index through the sum of the proportion of each pest or disease, which was multiplied by the respective impact coefficient.

$$
\begin{aligned}
\text { San }= & 1\left(\frac{\text { OA Cflo }}{5 \text { oaks }}\right)+3\left(\frac{\text { OA Cund }}{5 \text { oaks }}\right) \\
& +5\left(\frac{\text { OA Barkb }}{5 \text { oaks }}\right)+5\left(\frac{\text { OA Bmed }}{5 \text { oaks }}\right)
\end{aligned}
$$

$O A$ is the oaks affected by each pest or disease.

Data analysis

Prior to data analysis and in order to avoid multicollinearity among variables, we performed data reduction procedures. According to Tabachnick and Fidell (2001), we assessed all pairwise correlations through Spearman correlation coefficients and retained only one in each pair of highly correlated variables 
Table 2 Environmental variables recorded at each one of the sampling sites

\begin{tabular}{|c|c|}
\hline Environmental variables & Code \\
\hline \multicolumn{2}{|l|}{ Geographical variables } \\
\hline Geographical location (coordinates) & Point \\
\hline Identification of the four areas surveyed & $\begin{array}{r}\text { Study } \\
\text { area }\end{array}$ \\
\hline Altitude (m) & Alt \\
\hline \multicolumn{2}{|l|}{ Vegetation features } \\
\hline Shrubs density & Shrubs \\
\hline Trees density & Trees \\
\hline $\begin{array}{l}\text { Woody richness including tree and shrub species } \\
\text { (categorical; 1-one or two woody species; } \\
\text { 2-three or more woody species) }\end{array}$ & Woody \\
\hline \multicolumn{2}{|l|}{ Management practices } \\
\hline Trunk diameter at breast height $(\mathrm{cm})$ & $\mathrm{DBH}$ \\
\hline Year of the last cork removal & Debark \\
\hline $\begin{array}{l}\text { Type of edge (categorical; 1-open area; } 2 \text {-shrubs } \\
\text { and vineyards; } 3 \text {-eucalyptus, pine plantations, } \\
\text { orchards, olive groves) }\end{array}$ & Edge \\
\hline Distance to the edge $(\mathrm{m})$ & EdgeD \\
\hline \multicolumn{2}{|l|}{ Sanitary status } \\
\hline Presence/absence of Biscogniauxia mediterranea & Bmed \\
\hline Presence/absence of Coroebus florentinus damage & Cflo \\
\hline Presence/absence of Coroebus undatus damage & Cund \\
\hline $\begin{array}{l}\text { Presence/absence of bark beetles (Platypodidae } \\
\text { and Scolytidae) and cerambycids } \\
\text { (Cerambycidae) damage }\end{array}$ & BarkB \\
\hline
\end{tabular}

$(r>10.71)$ for further analyses. Only a pair of variables showed strong collinearity Altitude and Study Area $(\mathrm{r}=0.934)$. Altitude was removed due to the autocorrelation of this variable between sampling sites belonging to the same study area.

We used one-way ANOVA (Zar 1999) to determine if there were differences between areas in terms of ecological guilds and environmental variables.

We modelled the effects of environmental variables in function of groups of species through linear mixedeffects models (Pinheiro and Bates 2000). We treated Study Area as random effect and all other explanatory variables as fixed effects. To deal with model selection uncertainty we analysed our data based on the information theoretic approach (ITA) (Burnham and Anderson 2002). In the analyses of species groups (bird richness of every guild), Shannon's diversity index and total species richness, we considered as fixed effects the following six variables which are representative of the heterogeneity inside the montado: shrubs density; trees density; woody richness; type of edge; distance to edge; and sanitary index.

We generated all possible models combining from none to seven explanatory variables. We used this option, classified as data dredging (Burnham and Anderson 2002), because all explanatory variables considered could potentially influence the response variables. Using all possible combinations we guaranteed that the explanatory variables were included in the model-averaging procedure in identical manner. In accordance with Burnham and Anderson (2002), we fitted the models one by one and ordered them by their values of AICc (second-order Akaike's information criterion). We used AICc as a measure of information loss for each candidate model, with the best fitting model having the lowest AICc and the highest Akaike weight (wi), which measures the posterior probability of a given model being true, given the data and the set of competing candidate models (Burnham and Anderson 2002). Additionally, we also calculated the number of parameters (degrees of freedom), log-likelihood value and AICc difference ( $\triangle \mathrm{AICc})$, and the modelaveraged coefficients of all explanatory variables for each model (Burnham and Anderson 2002; Lukacs et al. 2010; Symonds and Moussalli 2011). Finally, we estimated the relative importance of each explanatory variable, by adding the Akaike weights of all models in which the variable appeared (Burnham and Anderson 2002). The relative importance of the variables that appear in all top models tends towards 1 . In variables that only appear in less likely models, their relative importance tends towards 0 . We then ranked the explanatory variables according to their relative importance, and the direction and magnitude of the effect of each variable was based on the modelaveraged coefficients (Burnham and Anderson 2002).

We carried out the statistical analysis using SPSS 21 for Windows (IBMCorp. 2012) and software R v. 3.0.2 (RCoreTeam 2013), with package MuMIn (Barton 2014) and nlme (Pinheiro et al. 2014).

\section{Results}

General results

From 74 species recorded in surveys, we used 50 in the analyses and hereafter we will refer only to those. 
Almost $40 \%$ of these species show some level of threat, according to the Species of European Conservation Concern (SPEC) (BirdLife International 2004) or have conservation status by the Portuguese Red Book of Vertebrates (Cabral et al. 2005) or the IUCN Red List (BirdLife International 2014) (Appendix I). We detected 17 of the 50 species in all areas. On the other hand, we detected five bird species exclusive from Romeu, three exclusive from Monfurado and Lezírias and one exclusive from Grândola (Appendix I). Average species richness and standard deviation, per point count, was $6.8 \pm 1.3$ in Grândola, $7.3 \pm 1.2$ in Romeu, $8.5 \pm 2.1$ in Lezírias and $11.2 \pm 2.4$ in Monfurado.

\section{Environmental variables}

In order to evaluate how our environmental variables range along the four areas we run one-way ANOVAs for each variable, with a Bonferroni correction post hoc test (Table 3). The average age of cork removal (Debark) and the distance to the edge (EdgeD) were similar between all areas. On the contrary, Altitude was significantly different among all areas.

Although shrub coverage was higher in Grândola, being almost the double than in Lezírias and Monfurado, tree coverage and woody diversity were the lowest observed. Monfurado was the area with higher tree coverage and significantly different from all the others. Diversity of woody vegetation was higher in Lezírias and Monfurado and statistically different from Grândola and Romeu. The oldest settlements were observed in Romeu and Lezírias (based on trunk diameter at breast high-DBH), being statistically different from Monfurado.

We observed a similar pattern for both Coroebus species, with lower values of affectation in Romeu and higher values in Grândola and Monfurado. In this sense, these areas were significantly different for both pests. Romeu emerges as the area with less evidence of affectation in regard to the sanitary status index.

\section{Bird guilds}

In order to evaluate how our species ranged along the four areas we run a one-way ANOVA among areas for each species guild, with a Bonferroni correction post hoc test. Significant differences were observed between areas for all guilds analyzed, and also for total bird richness, species diversity and conservation status (Table 4). Monfurado was the area with highest species richness for all bird guilds, with the exception of farmland species. Lezírias had the highest values for this guild whereas it appears to be residual in Romeu. Romeu had the lowest value for species with conservation status, and Monfurado presented the highest species richness of this guild. As expected, based on guilds results, Monfurado stood out from the other areas regarding species diversity and total species richness. The other areas did not present significant statistical differences, with the exception of higher species richness in Lezírias than in Grândola.

Modelling bird guilds

We ranked the candidate models for each one of the response variables based on the AICc $(\Delta \mathrm{AICc}<2.00)$ and also estimated the relative importance of each variable (Table 5) (Burnham and Anderson 2002).

Farmland species: three variables-tree density, edge type, and woody species-were included in the set of best models (Table VI-supplementary material). Tree density assumed the greatest importance (0.92), being negatively associated with the richness of farmland species. Edge type also had a high relative importance (0.69), with these species being negatively influenced by the presence of non-agricultural edges. Woody species still had some relative importance. Patches with more woody species showed a greater richness of farmland birds.

Edge species: none of the variables showed an association with this group of species, the top ranked model being the null model (Table VI).

Forest generalists: although the null model was ranked in the best set of models (in fourth positionTable VI), we found it useful to discuss the variables that enter in the other models. These included three variables-sanitary index, woody species and tree density (Table 5); all positively associated with this guild.

Forest specialists: the most relevant variables in the candidate models were tree density, edge type, shrubs density and woody species. Sites with higher tree cover were most important to this species (1.00) being present in all models.

Conservation status: two variables-edge type and tree density-were included in the models, both influencing negatively the richness of species with 


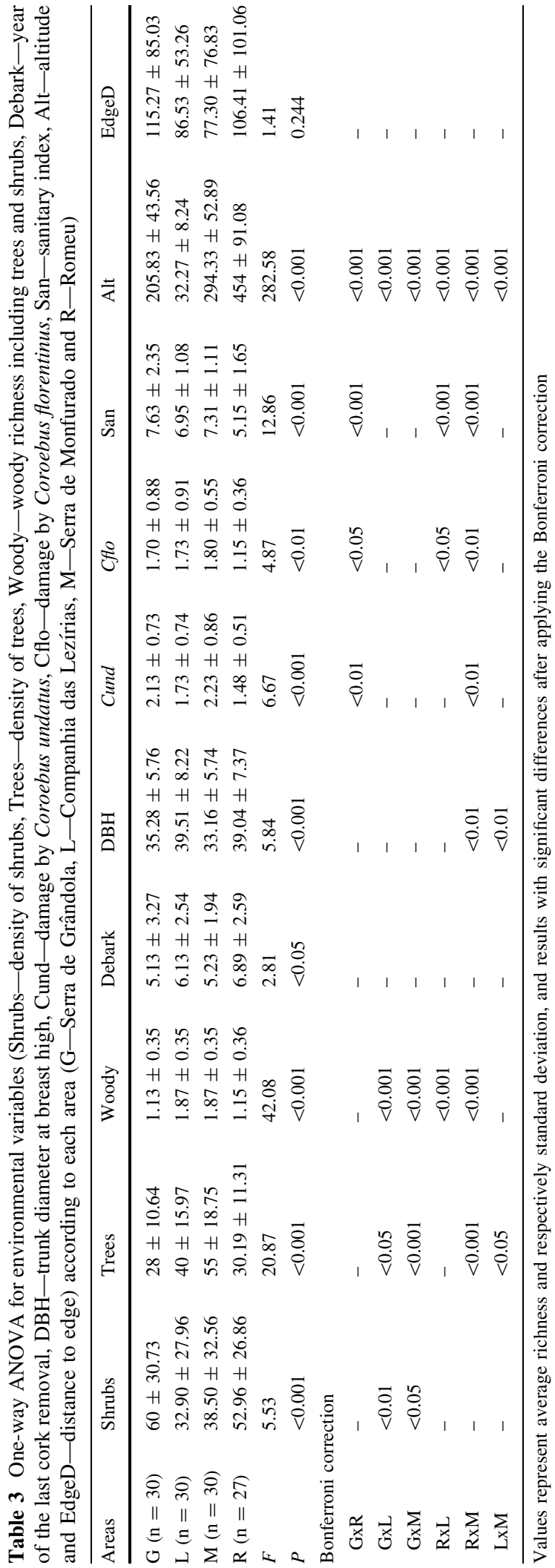

conservation status. The types of edge that negatively influenced species with conservation status were forest edges (e.g. eucalyptus, pine, orchards) and shrub edges.

Shannon's diversity index: two variables assumed higher importance, and positively influence species diversity: sanitary index (0.95) and woody species (0.88).

Species richness: as in the case of the Shannon's diversity index, the variables included in the models were woody species and sanitary index.

\section{Discussion}

In a first approach we characterized areas and associated bird guilds in order to have a better perception of their similarities and differences, allowing us to distinguish eventual patterns arising from regional influence. The analysis showed the amplitude of montados evaluated throughout the country (Table 3), and even inside of each area, this is particularly relevant when we try to assess associations between bird guilds and HNV features.

The highest richness for most guilds (except for farmland species) was associated with Monfurado (Table 4), this area revealing high amplitude in variables associated with landscape heterogeneity (trees, woody and shrubs; Table 3). These results are in line with what has been documented by other authors (e.g. Blondel and Aronson 1999; Díaz et al. 2003; Harrop 2007). Actually, the heterogeneous pattern of wooded matrix with open areas, scattered woodlands and undisturbed patches of Mediterranean forest and scrublands, creates a patchwork of habitats which is a trait of montado landscape, and induces the highest richness in breeding bird communities in the Iberian Peninsula (e.g. Tellería 2001). So, areas that encompass higher densities of shrubs and trees and that are more diverse in woody species have greater potential of being considered good habitats for a large number of species, including species of conservation concern (e.g. redstart Phoenicurus phoenicurus and crested tit Parus cristatus).

Species belonging to the farmland guild, including thekla lark (Galerida theklae), stonechat (Saxicola torquata) and corn bunting (Emberiza calandra), are tolerant to the presence of trees in their breeding sites. Therefore, they can occur in montados, contrarily to 
Table 4 One-way ANOVA for species richness by ecological guild ( $\mathrm{Fa}$-farmland species, ES—edge species, FoG-forest generalists, FoS-forest specialists, ConSt-conservation status), Shannon's diversity index (ShInd) and total species

\begin{tabular}{|c|c|c|c|c|c|c|c|}
\hline Areas & $\mathrm{Fa}$ & ES & FoG & FoS & ConSt & ShInd & SpRich \\
\hline $\mathrm{G}(\mathrm{n}=30)$ & $0.97 \pm 1.10$ & $0.50 \pm 0.63$ & $4.03 \pm 1.16$ & $1.30 \pm 0.70$ & $1.20 \pm 0.85$ & $0.79 \pm 0.10$ & $6.80 \pm 1.32$ \\
\hline $\mathrm{L}(\mathrm{n}=30)$ & $1.90 \pm 1.21$ & $1.20 \pm 0.93$ & $4.37 \pm 1.38$ & $1.07 \pm 0.94$ & $1.57 \pm 0.90$ & $0.86 \pm 0.12$ & $8.53 \pm 2.10$ \\
\hline$M(n=30)$ & $1.77 \pm 1.43$ & $1.80 \pm 1.00$ & $5.77 \pm 2.37$ & $1.90 \pm 1.37$ & $2.23 \pm 1.41$ & $0.99 \pm 0.15$ & $11.23 \pm 2.43$ \\
\hline $\mathrm{R}(\mathrm{n}=27)$ & $0.15 \pm 0.36$ & $0.85 \pm 0.95$ & $5.19 \pm 1.39$ & $1.15 \pm 0.86$ & $0.63 \pm 0.74$ & $0.83 \pm 0.08$ & $7.33 \pm 1.24$ \\
\hline$F$ & 14.96 & 11.69 & 6.77 & 4.17 & 12.62 & 16.56 & 33.61 \\
\hline$P$ & $<0.001$ & $<0.001$ & $<0.001$ & $<0.01$ & $<0.001$ & $<0.001$ & $<0.001$ \\
\hline \multicolumn{8}{|c|}{ Bonferroni correction } \\
\hline GxR & $<0.05$ & - & - & - & - & - & - \\
\hline GxL & $<0.01$ & $<0.05$ & - & - & - & - & $<0.01$ \\
\hline GxM & $<0.05$ & $<0.001$ & $<0.01$ & - & $<0.01$ & $<0.001$ & $<0.001$ \\
\hline $\mathrm{RxL}$ & $<0.001$ & - & - & - & $<0.01$ & - & - \\
\hline $\mathrm{RxM}$ & $<0.001$ & $<0.01$ & - & $<0.05$ & $<0.001$ & $<0.001$ & $<0.001$ \\
\hline LxM & - & - & $<0.01$ & $<0.05$ & - & $<0.001$ & $<0.001$ \\
\hline
\end{tabular}

Values represent average richness and respectively standard deviation, and results with significant differences after applying the Bonferroni correction

what happens to strict farmland species (Moreira et al. 2005). This guild is associated with scattered montados and to agricultural edges, decreasing its densities with the proximity of forested edges, like eucalyptus or pine plantations. Such tendency was also recorded by Reino et al. (2009) with the same group of species but in a farmland context. According to such relations between birds and habitat, the farmland species occurring in montados can be defined as generalist farmland species. Therefore, the diversity of woody vegetation may provide them with more ecological niches; however, shrub coverage must be low since most of these species nests in open ground.

The fuzziness of the montado may be the reason for the absence of strong relations between the variables considered and edge species. In montado these species are associated with the decreasing density of vegetation (e.g. trees and shrubs) more than with the abrupt transition between farmland and forestry patches or early-successional habitats as in the case of Central and Northern Europe (e.g. Imbeau et al. 2003; Storch et al. 2005). Additionally, inside the guild there are species associated with different kinds of forest interfaces, for example: turtle dove (Streptopelia turtur), melodious warbler (Hippolais polyglotta) and cirl bunting (Emberiza cirlus) are mainly associated with forest—-farmland edges; wood lark (Lullula richness (SpRich) according to each area ( $\mathrm{G}$-Serra de Grândola, L-Companhia das Lezírias, M-Serra de Monfurado and $\mathrm{R}-\mathrm{Romeu}$ ) 


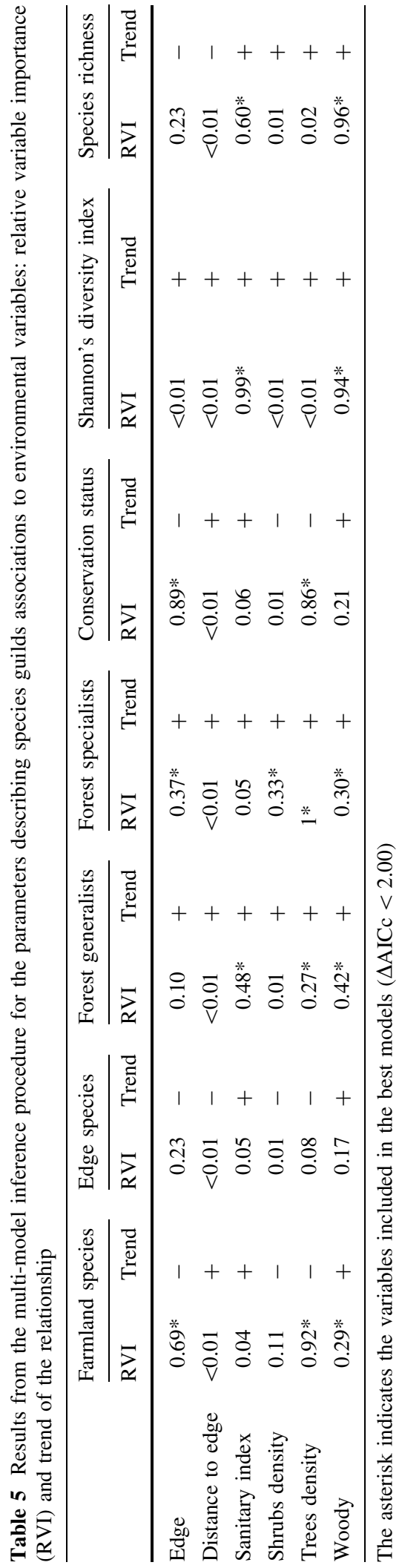

montado. Besides, these patches allow an increase of niche availability for species and can be used as an important evaluation element of $\mathrm{HNV}$ in Europe (Morelli 2013).

The occurrence of priority species for conservation is one of the key points for a site to be recognized as HNV. In our study these species are associated with more sparse montados and with farmland edge, in other words they tend to avoid more mature and complex sites. This trend is directly influenced by the existing imbalance between the species of this group: 16 out of 19 species (84\%) with some criteria of conservation are farmland or edge species associated with the interface forest-farmland. We suggest that this result should be considered with some caution because most of the threatened forest species that nesting in montado were not targeted by our study since they have large territories (e.g. raptors, black stork) and this could be another factor of bias. The inclusion of other conservation criteria must be considered, such as those proposed by Tavares (2009), based on species of which Portugal hosts significant populations at European level, thus having a responsibility for their conservation (e.g. Iberian chiffchaff Phylloscopus ibericus or serin Serinus serinus).

Species richness and species diversity showed the same trend, being positively associated with areas that have higher diversity of woody vegetation and higher values of sanitary index. The association between these two indices and the sanitary condition may reflect (1) the current state of conservation of montados and (2) the influence of the forest generalist species in the species taken as a whole. Most of these species were recorded along several sampling sites (e.g. blue tit Parus caeruleus, short-toed treecreeper Certhia brachydactyla, blackbird Turdus merula) which suggests that the global indexes were primarily influenced by the presence of forest generalist species. Cork oak decline has been reported in Southwestern Portugal since the 1890s (Cabral et al. 1992) and therefore, in the light of our results, it seems plausible to state that most of the surveyed areas are under some kind of threat.

\section{Conclusion}

The continuous gradient of land cover and fuzzy boundaries characteristic of montado (Pinto-Correia 
et al. 2011) are well expressed in the variables of density and diversity of vegetation and their association with the bird guilds evaluated. With the exception of the edge species, these variables were important to all the other bird groups (Table 5). The guilds under consideration mainly characterized a gradient of forest complexity, from the farmland species to the forest specialists, and perhaps they can be individually used as HNV indicators of a particular typology of montado, based on tree coverage: farmland species for scattered areas; and, on the opposite side of the range, forest specialists for more mature settlements or small well-preserved forest patches. We cannot say if all montado typologies can be classified as HNV, but we can define characteristic bird guilds for several typologies, and through the ratio between the species observed and the expected pool of species it should be possible to evaluate if a site may be classified as HNV. At a broader scale the universal measures of species diversity and species richness could also be used as HNV indicators.

The next steps on research should be focused on: (1) the creation and testing of a compound index with farmland, forest generalists and forest specialists species in order to create a reliable indicator of $\mathrm{HNV}$ for montados applicable to several scales, (2) the assessment of other HNV parameters for montado such as stone piles, ponds or fences, and (3) the integration of other species conservation criteria in addition to the traditional red lists.

Acknowledgments We would like to thank two anonymous reviewers whose comments helped to improve the manuscript. We also thank to Rui Lourenço, Pedro Salgueiro and Luís Gomes for invaluable comments and suggestions. This study was partially supported by Companhia das Lezírias S.A. and by the Portuguese Science Foundation through the Doctoral grants SFRH/BD/81602/2011 (Carlos Godinho) and SFRH/BD/87340/ 2012 (Pedro Pereira).

\section{References}

Andersen E, Baldock D, Bennett H, Beaufoy G, Bignal E, Brouwer F, Elbersen B, Eiden G, Godeschalk F, Jones G, McCracken D, Nieuwenhuizen W, van Eupen M, Hennekens S, Zervas G (2003) Developing a High Nature Value Farming area indicator. Internal report for the European Environment Agency.

APCOR (2012) Anuário da APCOR. Plenimagem
Barton K (2014) Multi-model inference. Version 1.10.0. http://cran.r-project.org/web/packages/MuMIn/index.html. Accessed 24 Sept 2014

Beaufoy G, Cooper T (2008) Guidance document to the member states on the application of the Hight Nature Value impact indicator. Institute for European Environmental Policy, Brussels

Bibby CJ, Burgess ND, Hill DA, Mustoe S (2000) Bird census techniques, 2nd edn. Academic Press, London

BirdLife International (2004) Birds in the European Union: a status assessment. BirdLife International, Wageningen

BirdLife International (2014) IUCN Red List for birds. http:// www.birdlife.org. Accessed 4 Aug 2014

Blondel J, Aronson J (1999) Biology and wildlife of the Mediterranean region. Oxford University Press, New York

Burnham KP, Anderson DR (2002) Model selection and multimodel inference: a practical information-theoretic approach. Springer, New York

Cabral MT, Ferreira MC, Moreira T, Carvalho EC, Diniz AC (1992) Diagnóstico das causas da anormal mortalidade dos sobreiros a Sul do Tejo. Scientia Gerundensis 18:205-214

Cabral M, Almeida J, Almeida P, Dellinger T, Almeida N, Oliveira M, Palmeirim J, Queiroz A, Rogado L, Reis M (2005) Livro Vermelho dos Vertebrados de Portugal. Instituto da Conservação da Natureza, Lisboa

Carreiras JMB, Pereira JMC, Pereira JS (2006) Estimation of tree canopy cover in evergreen oak woodlands using remote sensing. For Ecol Manag 223:45-53

DGRF (2007) Inventário Florestal Nacional 2005/06. Direcção Geral dos Recursos Florestais, Lisboa

Díaz M, Pulido FJ, Marañón T (2003) Diversidad biológica y sostenibilidad ecológica y económica de los sistemas adehesados. Ecossistemas XII (3)

Godinho C, Rabaça JE (2011) Birds like it Corky: the influence of habitat features and management of 'montados' in breeding bird communities. Agrofor Syst 82(2):138-195

Harrop SR (2007) Traditional agricultural landscapes as protected areas in international law and policy. Agric Ecosyst Environ 121(3):296-307

Hoffmann J, Greef JM (2003) Mosaic indicators-theoretical approach for the development of indicators for species diversity in agricultural landscapes. Agric Ecosyst Environ 98(1-3):387-394

Hoogeveen Y, Petersen J-E, Balazs K, Higuero I (2004) High Nature Value farmland: characteristics, trends and policy challenges. European Environment Agency, Luxembourg

IBMCorp. (2012) IBM SPSS Statistics for Windows, Version 21.0. IBM Corp., Armonk, NY

Imbeau L, Drapeau P, Mönkkönen M (2003) Are forest birds categorised as "edge species" strictly associated with edges? Ecography 26(4):514-520

Joffre R, Rambal S, Ratte JP (1999) The dehesa system of southern Spain and Portugal as a natural ecosystem mimic. Agrofor Syst 45(1-3):57-79

Kleijn D, Kohler F, Báldi A, Batáry P, Concepción ED, Clough Y, Díaz M, Gabriel D, Holzschuh A, Knop E, Kovács A, Marshall EJP, Tscharntke T, Verhulst J (2009) On the relationship between farmland biodiversity and land-use intensity in Europe. Proc R Soc B 276(1658):903-909

Leal AI, Correia RA, Granadeiro JP, Palmeirim JM (2011) Impact of cork extraction on birds: relevance for 
conservation of Mediterranean biodiversity. Biol Conserv 144(5):1655-1662

Lukacs PM, Burnham KP, Anderson DR (2010) Model selection bias and Freedman's paradox. Ann Inst Stat Math 62: $117-125$

Moreira F, Beja P, Morgado R, Reino L, Gordinho L, Delgado A, Borralho R (2005) Effects of field management and landscape context on grassland wintering birds in Southern Portugal. Agric Ecosyst Environ 109(1-2):59-74

Morelli F (2013) Relative importance of marginal vegetation (shrubs, hedgerows, isolated trees) surrogate of $\mathrm{HNV}$ farmland for bird species distribution in Central Italy. Ecol Eng 57:261-266

Ojeda F, Arroyo J, Marañón T (1995) Biodiversity components and conservation of mediterranean healthlands in Southern Spain. Biol Conserv 72(1):61-72

Pereira P, Godinho C, Roque I, Marques A, Branco M, Rabaça JE (2014) Time to rethink the management intensity in a Mediterranean oak woodland: the response of insectivorous birds and leaf-chewing defoliators as key groups in the forest ecosystem. Ann For Sci 71(1):25-32

Pérez-Tris J, Bensch S, Carbonell R, Helbig A, Tellería J (2004) Historical diversification of migration patterns in a passerine bird. Evolution 58(8):1819-1832

Pinheiro JC, Bates DM (2000) Mixed-effects models in S and S-PLUS. Springer, New York

Pinheiro J, Bates D, DebRoy S, Sarkar D and R Core Team (2014) nlme: Linear and nonlinear mixed effects models. R package version 3.1-117, http://CRAN.R-project.org/ package $=$ nlme. Accessed 24 Sept 2014

Pinto-Correia T (1993) Threatened landscape in Alentejo, Portugal: the 'montado' and other 'agro-silvo-pastoral' systems. Landsc Urban Plan 24(1-4):43-48

Pinto-Correia T, Almeida M (2013) Tentative identification procedure for HNV Montados. In: ICAAM International Conference 2013: Acknowledging the MONTADOS and DEHESAS as High Nature Value Farming Systems, Évora, Portugal, 6-8 February.

Pinto-Correia T, Vos W (2004) Multifunctionality in Mediterranean landscapes-past and future. New Dimens Eur Lands 4:135-164

Pinto-Correia T, Ribeiro N, Sá-Sousa P (2011) Introducing the montado, the cork and holm oak agroforestry system of Southern Portugal. Agrofor Syst 82(2):99-104
Plieninger T (2007) Compatibility of livestock grazing with stand regeneration in Mediterranean holm oak parklands. J Nat Conserv 15(1):1-9

Rabaça JE (1990) The influence of shrubby understory in breeding bird communities of cork oak (Quercus suber) woodlands in Portugal. Portugaliae Zoologica 1(1):6

RCoreTeam (2013) A language and environment for statistical computing. R Foundation for Statistical Computing, Vienna, Austria

Reino L, Beja P, Osborne PE, Morgado R, Fabião A, Rotenberry JT (2009) Distance to edges, edge contrast and landscape fragmentation: interactions affecting farmland birds around forest plantations. Biol Conserv 142(4):824-838

Scarascia-Mugnozza G, Oswald H, Piussi P, Radoglou K (2000) Forests of the Mediterranean region: gaps in knowledge and research needs. For Ecol Manag 132(1):97-109

Storch I, Woitke E, Krieger S (2005) Landscape-scale edge effect in predation risk in forest-farmland mosaics of Central Europe. Landsc Ecol 20(8):927-940. doi:10.1007/ s10980-005-7005-2

Symonds MR, Moussalli A (2011) A brief guide to model selection, multimodel inference and model averaging in behavioural ecology using Akaike's information criterion. Behav Ecol Sociobiol 65(1):13-21

Tabachnick BG, Fidell LS (2001) Using multivariate statistics. Allyn and Bacon, Boston

Tavares JP (2009) Uma perspectiva internacional sobre as prioridades de conservação da avifauna Portuguesa. Actas do VI Congresso de Ornitologia da Sociedade Portuguesa para o Estudo das Aves. Elvas

Tellería JL (2001) Passerine bird communities of Iberian dehesas: a review. Anim Biodivers Conserv 24(2):67

Telleria JL, Baquero R, Santos T (2003) Effects of forest fragmentation on European birds: implications of regional differences in species richness. J Biogeogr 30:621-628

Whelan CJ (2001) Foliage structure influences foraging of insectivorous forest birds: an experimental study. Ecology 82:219-231

Willson MF (1974) Avian community organization and habitat structure. Ecology 55:1017-1029

Zar JH (1999) Biostatistical analysis, 4th edn. Prentice Hall, New Jersey 